\title{
No plans to ban tobacco sales in BC drugstores
}

$\mathrm{B}$ ritish Columbia often receives praise for its success in reducing smoking, but many health advocates lament the province's steadfast refusal to join the rest of Canada in banning tobacco sales in drugstores.

The subject of cigarettes in pharmacies has been much discussed of late, following the recent announcement by CVS Caremark, the second-largest drugstore chain in the United States, that it will soon quit selling tobacco products. That decision received an overwhelmingly positive response from the American public, and for good reason, says Paul Billings, senior vicepresident of advocacy and education for the American Lung Association.

"It is inconsistent for a company trying to promote health and wellness to be selling a lethal product like tobacco," says Billings.

Since Manitoba removed cigarettes from pharmacies in 2013, BC has been the lone province in Canada to permit the practice. When he was appointed health minister of BC in June 2013, Terry Lake thought instituting a ban would be among his first orders of business. But Lake says he came to see the sale of tobacco products in drug stores, where would-be-quitters can consult pharmacists, as a sort of harmreduction strategy.

"You have the opportunity to interact with a health professional about smoking-cessation programs," says Lake. "Some have argued that this is such a dangerous substance that it should be sold only in drugstores."

Despite pressure from antismoking groups to change his mind, Lake says the decision remains about results, not optics. "If someone can show me evidence that taking tobacco out of pharmacies will reduce smoking rates, I'm willing to look at that."

According to Jack Boomer, director of the Clean Air Coalition of BC, however, simply having cigarettes on drugstore shelves sends a terrible message. "In drugstores, the pharmacy is at the

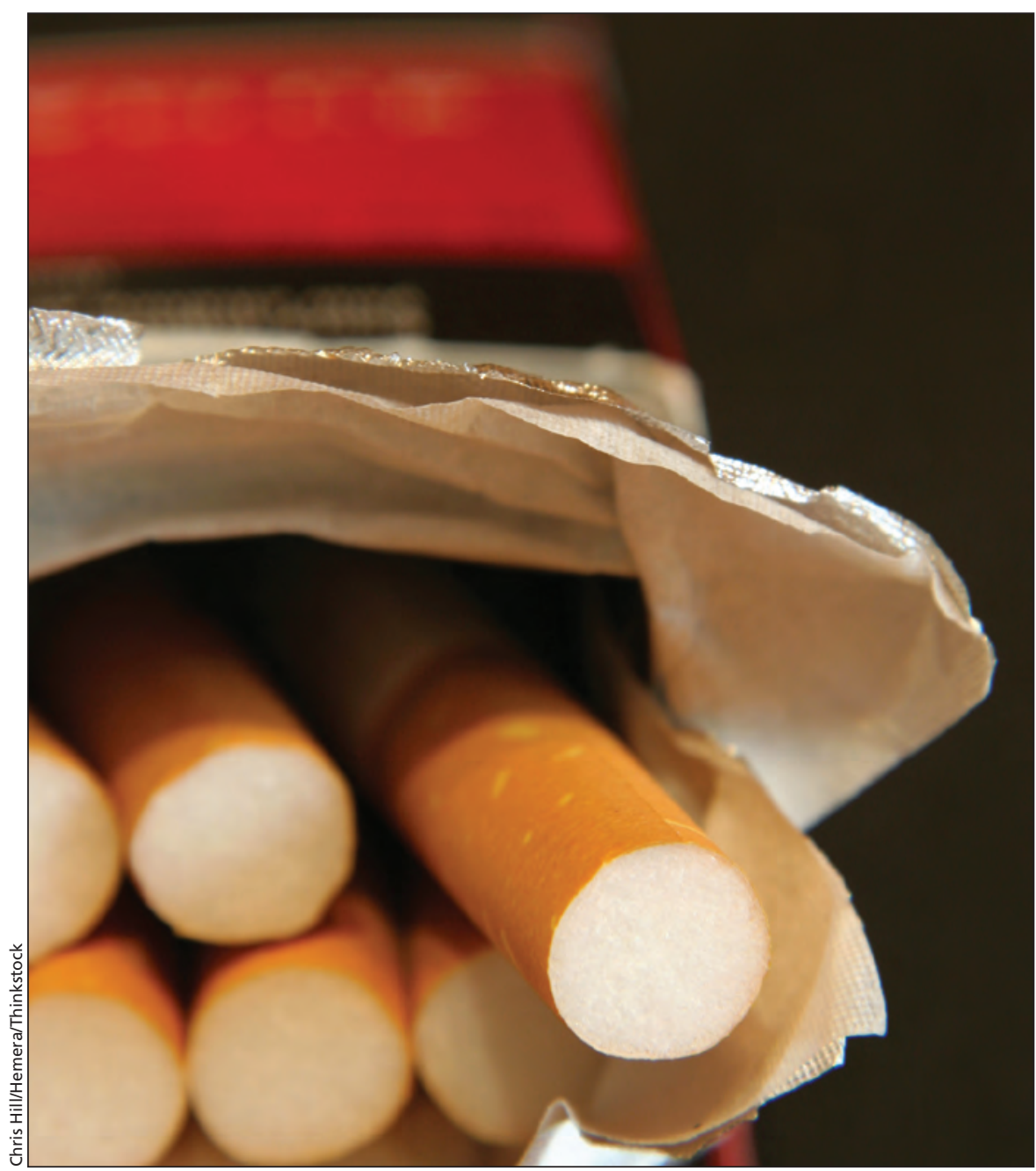

Selling tobacco products in drugstores allows smokers to interact with pharmacists about smoking-cessation programs, says BC Health Minister Terry Lake.

back and tobacco products are sold at the front, as you are leaving, and people know they are there. It's like Dracula going to the store and there is a blood bank as you leave. Maybe I should top up my supply for the week."

Overall, $\mathrm{BC}$ has done a great job at reducing smoking, says Boomer. Its smoking rate of $13.2 \%$ is the lowest in Canada (national average: 16.1\%). The government offers a generous smokingcessation program, providing free prescription drugs and nonprescription nicotine replacement therapies. During its recent budget, the province raised taxes on cigarettes by 32 cents a pack.
Despite the low smoking rate, though, BC's large population means it still has the third highest number of smokers of any province, says Boomer, and that's "a heck of a lot of people smoking." And the fact that cigarettes are available in a retail outlet that promotes health contributes to the misguided notion that they are normal products, says Boomer. Even if there isn't a ban, he says, drugstore owners should realize stocking such dangerous items is a disservice to their customers.

"If you put customers first, why would you sell a product that kills half of users when used as intended?" 
The answer to that question, according to John Tse, is that it allows drugstores to target tobacco users and offer them assistance from pharmacists and literature on quitting. Tse is the vice-president of pharmacy for London Drugs, which sells tobacco products in all its $\mathrm{BC}$ stores. If it stopped selling cigarettes, he says, smokers would simply buy them elsewhere, likely in locations without health professionals or smoking-cessation products.

Tse says London Drugs has distrib- uted about 250000 pamphlets with information on how to quit to smokers. He says tobacco products are not a "money maker" for London Drugs, and though it might be a good public relations move to stop selling them, the company sees itself as having a role to play in the fight against tobacco use.

"Our position, and our belief, is that we want do everything we can to stop smoking and to help people quit," says Tse. "Our goal is to actually stamp out smoking."

But according to renowned tobacco control expert Simon Chapman, handing smokers tips on how to quit isn't effective. "I know of no evidence that passing pamphlets to smokers while selling them cigarettes has any impact whatsoever," Chapman, a professor of public health at the University of Sydney, in Australia, writes in an email. "Moreover, I'd be astonished if the rate at which such interactions occurred would be more than $1 \%$." - Roger Collier, CMAJ

\section{Low rates of immunity in adults behind H1N1 resurgence}

$\mathrm{T}$ he 2009 pandemic strain of H1N1 influenza was back in Canada this year, despite an effective vaccine and very little mutation in the virus, researchers say. Instead, they point to a low level of seroprotection in adults aged 40 to 65 as the likely culprit.

Lack of previous exposure and of vaccination have probably combined to create a "pocket of residual susceptibility," says Dr. Danuta Skowronski, epidemiology lead for influenza and emerging respiratory pathogens at the $\mathrm{BC}$ Centre for Disease Control. Skowronski and colleagues at The Canadian Primary Care Sentinel Surveillance Network published the findings earlier this month in Eurosurveillance and presented them at a World Health Organization (WHO) meeting on influenza vaccine in Geneva, Switzerland, Feb. 20.

An estimated $90 \%$ of influenza strains detected in Canada in the 2013/ 14 season to date are $\mathrm{H} 1 \mathrm{~N} 1$, according to the study, which used a case-control design to analyze 792 isolates from patients with respiratory illness presenting at sentinel surveillance sites in the five most populous provinces.

Skowronski says she was "pleasantly surprised" that this year's flu vaccine was $75 \%$ effective, according to the study's calculations. "I presented these results to the vaccine strain committee of the WHO, and they have recommended that the same vaccine be retained."

She was also surprised by the viral analysis, which showed that "both antigenically and genetically the virus is

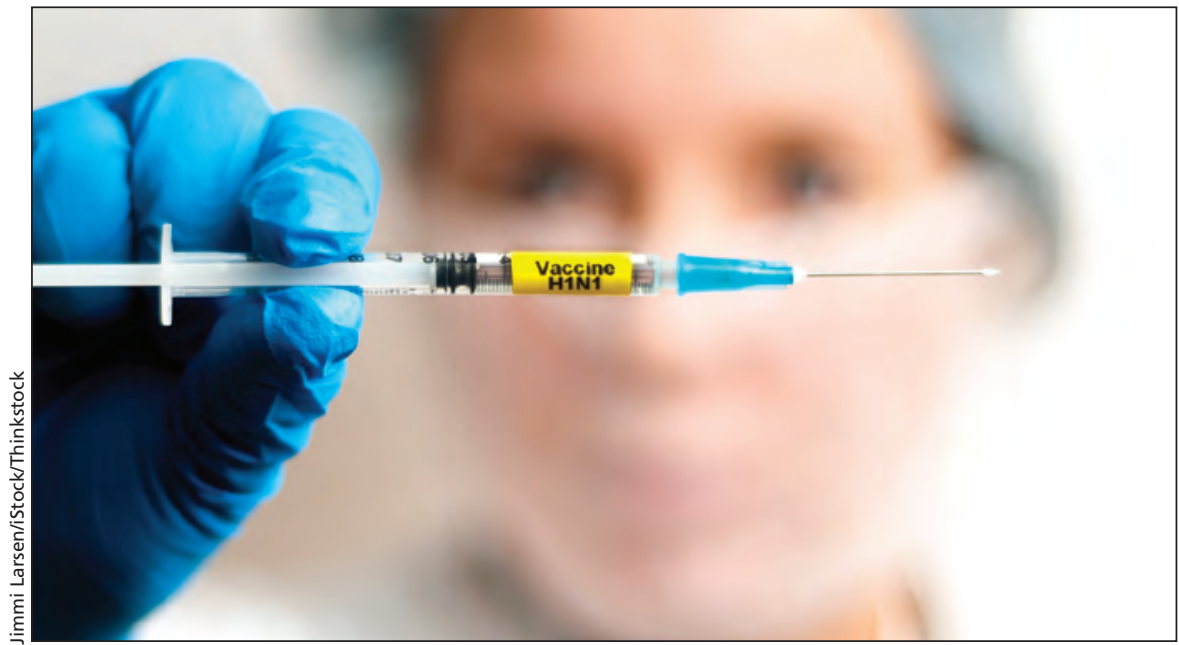

Middle-aged adults have only a $30 \%$ seroprotection rate against $\mathrm{H} 1 \mathrm{~N} 1$, but vaccination and infection history are not known.

well-conserved. It hasn't changed despite having circulated around the world since 2009."

Why then, has H1N1 come back, although at levels well below those in 2009/10 flu season? A serologic survey conducted last summer in British Columbia (a follow-up to a similar survey conducted after the pandemic in 2010 and published in CMAJ) shows a U-shaped protection pattern by age.

"We have found high rates of protection in those over 80 years of age, even before the pandemic," thanks to their exposure to a similar virus that circulated in the 1930s, says Skowronski. As well, children have high seroprotection rates, probably as a result of high rates of exposure and vaccination in 2009.

But middle-aged adults have only a
$30 \%$ seroprotection rate. "We don't know the vaccination or infection history" of patients in the serologic survey, explains Skowronski, but she thinks that the virus is now "working its way through adult contact networks."

However, rates of hospitalization and death due to H1N1 this season "pale in comparison with 2009," Skowronski hastens to point out, as a result of greater overall immunity in the population. Patients hospitalized this season tend to have underlying chronic conditions, including obesity, as a risk factor. "These patients are disproportionately affected," she says, "We want to get our immunization message to them." - Carolyn Brown, Ottawa, Ont.

CMAJ 2014. DOI:10.1503/cmaj.109-4740 